Wisber Wiryanto

\title{
Replikasi Model Inovasi Pelayanan Administrasi Kependudukan Di Indonesia
}

\author{
Wisber Wiryanto \\ Pusat Inovasi Administrasi Negara, Lembaga Administrasi Negara \\ *wisberwiryanto@yahoo.com
}

\begin{abstract}
Abstrak
Kementerian/lembaga/daerah yang menghasilkan inovasi terbaik dalam kompetisi inovasi pelayanan publik memperoleh penghargaan top-99 perlu dijadikan contoh dengan mereplikasi model inovasinya untuk peningkatan kualitas layanan publik instansi lainnya. Oleh karena itu, dilakukan kajian mencari model inovasi pelayanan administrasi kependudukan (adminduk) yang dapat direplikasi, dengan rumusan permasalahan, apa model inovasi pelayanan adminduk yang dapat direplikasi? Bagaimana cara mereplikasi model inovasi pelayanan tersebut? Metode penelitian kajian pustaka digunakan dengan memanfaatkan referensi, dokumen dan data yang relevan. Teknik accidental sampling digunakan untuk mengambil sampel sejumlah 10 instansi yang diberi penghargaan inovasi pelayanan adminduk top-99 tahun 2018, 2019 dan 2020, kemudian melakukan analisis data deskriptif kualitatif sehingga diperoleh model inovasi pelayanan adminduk yang dapat direplikasi. Kajian dilakukan semester pertama tahun 2020. Hasil kajian menemukan model inovasi pelayanan adminduk sebanyak 12 inovasi terbaik yang dapat direplikasi oleh instansi lainnya. Replikasi model tersebut dapat dilakukan dengan cara adopsi, adaptasi dan modifikasi. Instansi daerah lain perlu mereplikasi model tersebut untuk meningkatkan kualitas layanan adminduk.
\end{abstract}

Kata Kunci: Administrasi kependudukan, inovasi pelayanan, model inovasi, replikasi

\section{Pendahuluan}

Pelayanan administrasi kependudukan (adminduk) merupakan pelayanan yang penting dan strategis karena merupakan kunci pelayanan baik di sektor publik maupun sektor bisnis didasarkan kepada adanya kepemilikan dokumen kependudukan. Di samping itu, pelayanan administrasi kependudukan mempunyai ruang lingkup yang luas mencakup semua penduduk Indonesia sejak lahir sampai meninggal; dan dinamika perubahan kependudukan yang terjadi dari waktu ke waktu juga mempengaruhi kompleksitasnya. Oleh karena itu, pelayanan ini menjadi titik sentral bidang pelayanan lainnya, seperti pelayanan pendidikan, kesehatan, sosial dan ekonomi, dan lain-lain.

Pelayanan adminduk dilaksanakan oleh instansi Dinas Kependudukan dan Catatan Sipil (Dukcapil). Instansi ini tersebar di 34 (tigapuluh empat) provinsi; dan 416 (empatratus enambelas) kabupaten; serta 98 (sembilanpuluh delapan) kota. Kualitas pelayanan di masingmasing instansi tersebut bervariasi karena dipengaruhi oleh kondisi geografis, permasalahan lokal dan kemampuan manajemen yang berbeda dalam mengimplementasikan kebijakan.

Upaya peningkatan kualitas pelayanan adminduk terus dilakukan dengan menerbitkan peraturan perundang-undangan yang dijadikan sebagai acuan kebijakan pelayanan adminduk; dan mengatasi permasalahan yang dihadapi. Peraturan perundang-undangan yang menjadi 
acuan kebijakan pelayanan adminduk adalah UU No. 24/2013 tentang Perubahan UU No. 23/2006 tentang Adminduk. UU Adminduk ini mengamanahkan kepada setiap pemerintah daerah kabupaten/kota agar menyelenggarakan urusan adminduk dengan baik. Selanjutnya telah diterbitkan pula berbagai peraturan dan petunjuk teknis untuk pelaksanaannya.

Permasalahan yang dihadapi adalah persoalan sistem dan manusia. Di samping itu, ada permasalahan global yang sangat mempengaruhi pelayanan adminduk yaitu terjadinya wabah pandemi Covid-19. Wabah tersebut telah menelan korban sebanyak setengah juta jiwa sampai dengan pertengahan tahun 2020 (Tempo 2020). Permasalahan tersebut dicarikan solusinya sebagai upaya meningkatkan kualitas pelayanan adminduk.

Kebijakan dan permasalahan tersebut merupakan faktor pendorong instansi pelayanan adminduk melakukan inovasi pelayanan. Contoh kebijakan yang mendorong adalah adanya penyelenggaraan kompetisi inovasi pelayanan publik (KIPP) tahunan yang memberikan penghargaan bagi inovasi pelayanan publik yang terbaik. Dalam kompetisi tersebut lahir inovasi pelayanan publik termasuk pelayanan adminduk yang memperoleh penghargaan terbaik (Top 99). Inovasi yang terbaik tersebut tentunya dapat dijadikan sebagai model atau contoh untuk memperbaiki pelayanan adminduk di daerah lainnya. Melalui penyelenggaraan kompetisi tersebut, pemerintah dapat mencari dan menemukan model inovasi layanan adminduk yang dapat direplikasi.

Dalam mencari model inovasi pelayanan adminduk yang dapat direplikasi (Kemenpanrb 2018), maka telah dilakukan pembahasan yang melibatkan pemangku kepentingan dari tiga instansi, sebagai berikut:

Pertama, pemangku kepentingan dari instansi Kementerian PANRB menyatakan, kompetisi Inovasi pelayanan publik yang diselenggarakan telah melahirkan banyak inovasi. Diharapkan juga menyebarkannya untuk diterapkan di tempat lain. Diantara layanan dukcapil (adminduk) di pemerintah kabupaten/kota alangkah baiknya kalau ada model inovasi yang bisa dijadikan model bagi daerah lain.

Ada 2 (dua) inovasi layanan adminduk yang meraih penghargaan, diantaranya inovasi KIA (Kartu Insentif Anak) dari Pemko Surakarta (Top 33, 25, 99 tahun 2014, 2015, 2017); dan inovasi Kakeku Datang (Kartu Keluargaku Data Ulang) dari Pemkab Gresik (Top 99 tahun 2016). Jika inovasi tersebut dapat diterapkan di daerah lain, akan membawa peningkatan pelayanan publik secara nasional. Saat ini Kementerian PANRB tengah mencari model layanan adminduk lain yang juga dapat direplikasi.

Kedua, pemangku kepentingan dari instansi Kemendagri berpendapat, model inovasi adminduk tersebut tidak semuanya bisa diterapkan di daerah lain, karena kondisi geografis yang berbeda maka inovasi tersebut harus disesuaikan dengan tempat dimana akan diterapkan. Ketiga, pemangku kepentingan dari instansi LAN mengusulkan, sebelum melakukan replikasi, perlu dilihat prakondisi daerah yang berhasil menerapkan inovasi tersebut; dan coaching clinic dengan innovator. Pembahasan diantara pemangku kepentingan tersebut menunjukkan urgensi mencari model inovasi pelayanan adminduk yang dapat direplikasi.

Sehubungan latar belakang permasalahan tersebut, maka dipandang perlu melakukan penelitian replikasi model inovasi pelayanan adminduk di Indonesia. Dengan rumusan permasalahan sebagai berikut: (1) Apa model inovasi pelayanan adminduk yang dapat direplikasi?; dan (2) Bagaimana cara mereplikasi model inovasi pelayanan adminduk? Penelitian ini diharapkan dapat menemukan model inovasi pelayanan adminduk sehingga bermanfaat sebagai masukan instansi pelayanan publik melakukan replikasi model inovasi pelayanan untuk meningkatkan kualitas pelayanan khususnya di bidang adminduk. 
Wisber Wiryanto

\section{Landasan Teori dan Pengembangan Model Penelitian}

Deskripsi landasan teori dan pengembangan model penelitian mencakup model konseptual, permasalahan dan kebijakan inovasi pelayanan adminduk, serta hasil penelitian yang relevan dengan penelitian ini. Pemerintah dalam pelayanan publik dihadapi berbagai faktor yang mempengaruhinya seperti terjadinya perubahan situasi dan kondisi, perkembangan iptek, permasalahan dan kebijakan. Dengan demikian, model inovasi pelayanan adminduk dijelaskan menurut konsep model, permasalahan dan kebijakan.

Konsep model inovasi pelayanan adminduk dan replikasinya: Model (Depdikbud 2008) adalah pola (contoh, acuan, ragam) dari sesuatu yang akan dibuat atau dihasilkan. Model berupa pola, contoh atau contoh dalam kaitannya dengan inovasi, dapat disebut sebagai model inovasi. Pengertian model dalam kaitannya dengan inovasi (LAN 2017: 16), sebagai berikut:

Model merupakan representasi dari sebuah realitas yang kompleks yang mempunyai fitur, elemen, dan komponen. Model disusun untuk memahami realitas secara lebih sederhana. Dia adalah abstraksi dari suatu proses atau fenomena yang telah dilucuti dari konteks partikularnya sehingga bersifat umum. Karena sifatnya yang umum tersebut, model dapat menjadi panduan untuk melakukan replikasi.

Dalam kaitannya dengan inovasi, maka pembentukan model inovasi dapat dilakukan dengan cara dan pendekatan, misalnya pendekatan skenario, aliran, kelas, atau perilaku. Dalam mengonstruksi model inovasi, semua cara sah untuk dilakukan. Namun yang penting hasilnya efektif dalam membantu memahami inovasi dengan sederhana. Model tersebut dapat diartikulasikan dalam bentuk gambar, bagan, atau skema.

Selanjutnya model inovasi dapat diperoleh dari berbagai sumber. Sumber model inovasi bermacam-macam (LAN 2017: 17), sebagai berikut:

Dia dapat berasal dari sebuah inovasi, biasanya berasal dari inovasi yang sifatnya best practice sehingga layak untuk digeneralkan dan menjadi rujukan replikasi. Model juga dapat berasal dari dua atau lebih inovasi yang serupa. Misalnya, inovasi pelayanan kesehatan jemput bola untuk ibu melahirkan di Dinas Kesehatan Kabupaten A, B, dan C. Untuk membentuk model inovasi dari dua atau lebih inovasi sejenis, maka pembuat model harus mampu melakukan sintesis dari inovasi tersebut. Model inovasi tersebut hendaknya (didokumentasikan) dipublikasikan melalui media agar publik mengetahuinya. Dari gambaran model tersebut dapat diketahui tata kelola inovasi, unsur-unsur yang terlibat berikut perannya, dan hubungan di antara mereka.

Contoh inovasi best practice tersebut, dapat ditelusuri dari sumbernya yaitu inovasi yang mendapatkan penghargaan pelayanan publik top-99 untuk dipilih dan dijadikan sebagai model inovasi pelayanan adminduk terbaik yang dapat direplikasi. Dengan tersedianya model tersebut, maka instansi yang ingin mereplikasi suatu inovasi mendapat gambaran/panduan cara melakukan inovasi. Dengan kata lain, hal ini menunjukkan arti pentingnya replikasi. Replikasi adalah proses, cara, meniru, penduplikatan (Depdikbud 2008: 1167). Dalam studi ini, pengertian tersebut digunakan untuk menjelaskan replikasi inovasi. Dapat direplikasi merupakan salah satu kriteria inovasi daerah (PP No. 38/2017, Pasal 6).

Replikasi inovasi dapat dilakukan berbagai cara. Instansi yang ingin mereplikasi dapat memilih melakukan adopsi, adaptasi atau modifikasi. Adopsi artinya pemungutan (Depdikbud 2008: 11), sehingga adopsi inovasi dapat diartikan sebagai memungut langsung atau menggunakan inovasi apa adanya. Cara lainnya adaptasi dan modifikasi. Adaptasi adalah penyesuaian terhadap lingkungan (Depdikbud 2008: 8), sehingga adaptasi inovasi merupakan inovasi dengan penyesuaian terhadap lingkungan. Selanjutnya, modifikasi adalah perubahan 
(Depdikbud 2008: 924), sehingga modifikasi inovasi merupakan perubahan inovasi. Dengan kata lain, adaptasi atau modifikasi dari model inovasi dapat dilakukan sesuai kebutuhan dan karakteristik khas instansi yang ingin mereplikasi. Instansi pereplikasi dapat mengubah tata kelola atau menambah dan mengurangi unsur (LAN 2017: 18). Dengan demikian, instansi yang ingin mereplikasi sebuah model inovasi dapat memilih cara melakukan adopsi, adaptasi atau modifikasi.

Transfer inovasi merupakan cara serupa replikasi. Transfer adalah memidahkan dari suatu tempat ke tempat lain (Depdikbud 2008: 1484). Dalam studi ini, yang dimaksud transfer adalah memindahkan inovasi dari instansi asal ke instansi penerima. Transfer inovasi bisa dilakukan dengan cara adopsi, adaptasi atau modifikasi. Adopsi adalah menggunakan inovasi dari daerah lain langsung apa adanya Adaptasi yaitu model inovasi yang direplikasi disesuaikan dengan kebutuhan lingkungannya; sedangkan modifikasi, yaitu rekayasa unsur-unsur inovasi dari model inovasi aslinya. Transfer inovasi melibatkan pihak instansi asal, instansi penerima dan fasilitator transfer. Hal ini diilustrasikan dalam skema (lihat gambar 1).

Cara transfer inovasi, dapat dilakukan melalui 4 (empat) tahapan: (1) Mempertemukan permintaan dan persediaan antara instansi asal dan penerima transfer inovasi. Fasilitator menjadi penghubung dan memfasilitasi komunikasi antara instansi asal dan penerima; (2) Menentukan ruang lingkup, merancang metode dan menyusun rencana kerja transfer; (3) Melakukan adaptasi inovasi kedalam lingkungan instansi penerima; dan (4) melaksanakan dan evaluasi transfer inovasi (Utomo 2014).

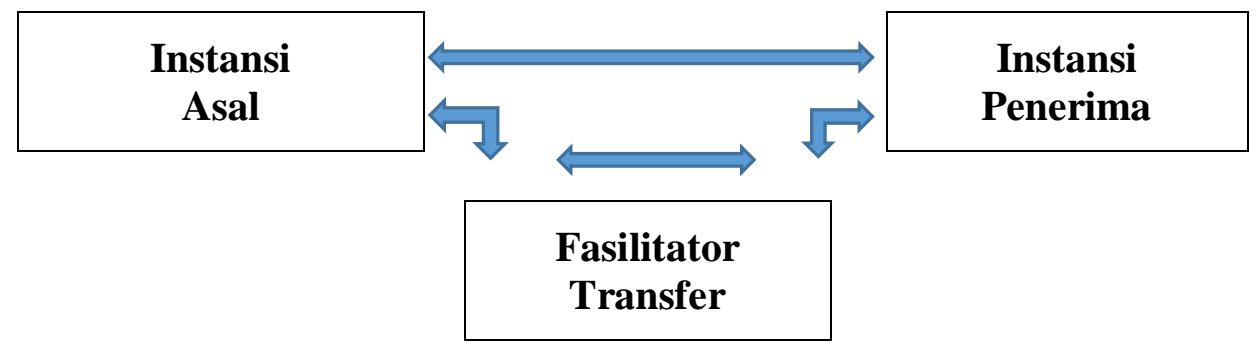

Gambar 1. Transfer Inovasi/Replikasi (Sumber: Utomo (2014)).

Dengan demikian, instansi yang ingin mentransfer model inovasi dapat memilih cara adopsi, adaptasi atau modifikasi inovasi. Cara yang paling sederhana yaitu dapat dilakukan dalam satu tahapan adalah adopsi inovasi. Sedangkan cara adaptasi atau modifikasi inovasi perlu melalui tahapan selengkapnya.

Cara lainnya, dinamakan delapan langkah transfer inovasi layanan publik, yang dibagi ke dalam tahap persiapan dan pelaksanaan (Apeksi 2016). Tahap pertama persiapan, terdiri dari empat langkah, meliputi: (1) Analisis kebutuhan, dilakukan agar inovasi yang ditransfer sesuai kebutuhan dan permasalahan daerah; (2) Pemetaan kondisi daerah dan inovasi dari daerah lain, dilakukan untuk mengetahui permasalahan dan solusinya serta sumberdaya yang dibutuhkan untuk mentransfer inovasi daerah contoh; (3) Pemetaan pemangku kepentingan, bertujuan untuk membangun proses dan meningkatkan partisipasinya untuk keberhasilan dan keberlanjutan program; (4) Membangun jejaring dengan daerah contoh, bertujuan memudahkan proses dan implementasi transfer praktik baik yang dilakukan.

Tahap kedua pelaksanaan, terdiri dari empat langkah, meliputi: (5) Pembentukan kelompok kerja, tujuannya agar proses transfer terlaksana secara sistematis, bermanfaat bagi masyarakat dan berkelanjutan; (6) Proses pembelajaran, dilakukan untuk meminimalisasi kesalahan dan mengatasi tantangan dalam menerapkan transfer inovasi; (7) Pendokumentasian proses pembelajaran, sehingga dapat dipelajari proses transfer inovasi dan pengembangannya; 
dan (8) Monitoring dan evaluasi: untuk mengantisipasi kendala, hambatan dan penyimpangan rencana transfer inovasi.

Seperti telah disebutkan, instansi yang ingin mentransfer sebuah model inovasi dapat memilih cara adopsi, adaptasi atau modifikasi. Tentunya cara sederhana dalam satu tahapan adalah melakukan adopsi inovasi karena bisa langsung digunakan. Sedangkan cara adaptasi atau modifikasi inovasi dilakukan melalui tahapan selengkapnya baru bisa digunakan.

Berdasarkan uraian langkah-langkah dan adanya kesamaan istilah replikasi dan transfer inovasi, maka peneliti lebih memilih menggunakan istilah replikasi daripada transfer inovasi, karena diakomodasi kebijakan inovasi daerah. Selanjutnya, penelitian ini mengusulkan alternatif replikasi model inovasi dengan langkah-langkah: (1) pemilihan dan penentuan model inovasi pelayanan adminduk: diawali dengan memilih model inovasi yang akan direplikasi, dan menentukan cara adopsi, adaptasi atau modifikasi; (2) persiapan penerapan model inovasi disesuaikan dengan kebutuhan, permasalahan dan sumberdaya daerah; (3) ujicoba model inovasi, agar penerapan model inovasi dapat dilakukan sesuai rencana; dan (4) finalisasi penerapan model inovasi pelayanan adminduk.

Catatan, pelaksana inovasi daerah melaksanakan ujicoba inovasi daerah, untuk menghasilkan inovasi daerah yang diinginkan. Berdasarkan peraturan inovasi daerah, maka inovasi daerah yang sederhana, tidak menimbulkan dampak negatif kepada masyarakat dan tidak mengubah penyelenggaraan pemerintahan daerah langsung diterapkan tanpa melalui uji coba inovasi daerah (PP No. 38/2017 Pasal 19).

Cara replikasi model inovasi pelayanan adminduk yang paling sederhana adalah melalui adopsi karena dengan hanya melalui tahapan pertama maka inovasi tersebut dapat langsung digunakan. Sedangkan mereplikasi dengan cara adaptasi dan modifikasi inovasi, sebaiknya dilakukan melalui tahapan selengkapnya.

Permasalahan pelayanan adminduk: Permasalahan yang dihadapi instansi pelayanan adminduk adalah persoalan sistem dan manusia, sebagai berikut: (1) Keterbatasan Sistem: (a) IT yang kurang mendukung: jaringan lemah bandwidth kecil, data tidak sinkron; (b) Sarana prasarana: perangkat komputer lambat, blanko terbatas, tidak ada ruang tunggu; (c) Prosedur panjang: RT-RW-Kelurahan-Kecamatan-Dinas. (2) (2) Faktor manusia: (a) SDM kurang kapabel: tidak memiliki sertifikasi kompetensi, sering mutasi; (b) Behavior: pungli, suap, calo, diskriminasi; (c) Partisipasi/kesadaran publik yang lemah; dan (d) Perilaku Petugas: Cemberut, tidak berorientasi pelayanan (Utomo 2017).

Permasalahan lainnya, permasalahan global sangat mempengaruhi pelayanan adminduk yaitu terjadinya pandemi Covid-19. Pada mulanya, wabah tersebut terjadi di Wuhan China akhir tahun 2019. Selanjutnya, wabah tersebut menyebar ke berbagai Negara, banyak penduduk yang tertular virus tersebut akibat kontak langsung. Sampai dengan pertengahan tahun 2020 wabah tersebut telah menelan korban sebanyak setengah juta jiwa (Tempo 2020). Permasalahan global tersebut menimbulkan dampak terjadinya perubahan kehidupan sosial ekonomi masyarakat, termasuk cara kerja di Indonesia. Instansi pelayanan adminduk perlu mengantisipasi permasalahan tersebut agar pelayanan berjalan dengan baik, dengan solusi inovasi layanan adminduk untuk meningkatkan kualitas pelayanan publik.

Kebijakan inovasi pelayanan adminduk: Pelayanan adminduk merupakan pelayanan yang dinamis yang tidak hanya dipengaruhi oleh dinamika penduduk; melainkan juga dipengaruhi oleh situasi, kondisi, permasalahan, dan kebijakan yang mendasarinya. Pelayanan adminduk memiliki instrument kebijakan berupa peraturan perundang-undangan; dan petunjuk pelaksanaan/teknisnya. Berikut ini penelusuran peraturan perundang-undangan tersebut baik 
yang mengatur pelayanan adminduk; maupun yang mengatur inovasi pelayanan publik, termasuk pelayanan adminduk.

Peraturan perundang-undangan sebagai pedoman adminduk adalah UU No. 24/2013 tentang Perubahan UU No. 23/2006 tentang Adminduk. Dengan UU Adminduk ini maka pemerintah mulai mendorong pemanfaatan data kependudukan untuk keperluan pelayanan publik, perencanaan pembangunan, alokasi anggaran, pembangunan demokrasi, dan penegakan hukum serta pencegahan kriminal (Pasal 58 ayat 4). Adminduk mencakup pengelolaan tidak kurang dari 23 (duapuluh tiga) jenis dokumen kependudukan. Terdiri dari 14 (empat belas) surat keterangan, 6 (enam) jenis akta, hingga biodata penduduk, 3 (tiga) jenis kartu yaitu Kartu Keluarga, KTP elektronik; dan Kartu Identitas Anak. Selanjutnya, UU Adminduk ini dijabarkan ke dalam Perpres No. 96/2018 tentang Persyaratan dan Tata Cara Pendaftaran Dukcapil. Perpres ini mendorong revolusi layanan publik dari berkarakter bureaucratic base berubah menjadi costumer base. Sehingga semua layanan Dukcapil orientasinya memberikan kemudahan kepada seluruh pemohon layanan untuk mewujudkan pelayanan yang membahagiakan rakyat.

Dalam rangka pelaksanaan peraturan tersebut, maka diturunkan petunjuk pelaksanaan dan teknisnya, antara lain: (1) Permendagri No. 9/2011 tentang Pedoman Penerbitan KTP Berbasis NIK Secara Nasional; (2) Permendagri No. 2/2016 tentang Kartu Identitas Anak; (3) Permendagri No. 19/2018 tentang Peningkatan Kualitas Layanan Adminduk; (4) Permendagri No.7/2019 tentang Pelayanan Adminduk secara Daring; (5) Inmendagri No. 470/837/SJ tanggal 7 Februari 2018 tentang Gerakan Indonesia Sadar Adminduk; dan (6) Surat No. 443.1/2978/Dukcapil per 16 Maret 2020 (yang telah diperpanjang masa berlakunya hingga pandemi Covid-19 berakhir).

Peraturan tersebut diturunkan dalam upaya peningkatan kualitas layanan adminduk, melalui perbaikan (inovasi) layanan terintegrasi (terpadu), jemput bola; dan perubahan jadwal/waktu pelayanan. Layanan terintegrasi yaitu layanan adminduk yang mengintegrasikan data kependudukan untuk mewujudkan single identity number; atau inovasi layanan adminduk terpadu yang terdiri dari berbagai jenis layanan adminduk yang output-nya diberikan sebagai satu paket dan tidak perlu diminta tetapi diberikan sekaligus. Layanan online-daring yaitu layanan proses pengurusan dokumen kependudukan yang pengiriman data/berkas persyaratannya menggunakan media elektronik berbasis web dengan memanfaatkan fasilitas teknologi, komunikasi dan informasi. Layanan jemput bola, yaitu layanan proses pengurusan dokumen kependudukan hingga pendistribusiannya kepada penduduk yang bersangkutan. Di samping itu, layanan dukcapil go digital; dan layanan anjugan dukcapil mandiri.

Di samping itu, pelayanan adminduk mengacu peraturan perundang-undangan pelayanan publik. UU No. 25/2009 tentang Pelayanan Publik yang mengatur ruang lingkup pelayanan publik meliputi pelayanan barang publik dan jasa publik serta pelayanan administratif. Asas penyelenggaraan pelayanan publik ditentukan meliputi: kepentingan umum; kepastian hukum; kesamaan hak; keseimbangan hak dan kewajiban; keprofesionalan; partisipatif; persamaan perlakuan/tidak diskriminatif; keterbukaan; akuntabilitas; fasilitas dan perlakuan khusus bagi kelompok rentan; ketepatan waktu; dan kecepatan, kemudahan, dan keterjangkauan. Pelayanan publik diselenggarakan dalam berbagai bidang antara lain di bidang kesehatan dan pendidikan, termasuk pelayanan adminiduk.

Di samping itu, sebagai acuan kebijakan inovasi pelayanan publik, maka telah diterbitkan PP No. 38/2017 tentang Inovasi Daerah. Dalam peraturan tersebut dijelaskan salah satu kriteria inovasi daerah adalah dapat direplikasi. Kajian ini relevan dengan replikasi tersebut, yaitu ingin mengetahui model inovasi pelayanan adminduk yang dapat direplikasi. Selanjutnya, diturunkan Peraturan Kementerian PANRB No. 30/2014 tentang Pedoman Inovasi Pelayanan Publik. Dalam pedoman tersebut dijelaskan, inovasi pelayanan publik 
adalah sebuah terobosan pelayanan publik yang merupakan gagasan ide kreatif orisinil dan atau adaptasi/modifikasi yang memberikan manfaat bagi masyarakat baik secara langsung maupun tidak langsung.

Tujuan pembangunan inovasi pelayanan publik untuk menjaring dan menumbuhkan pengetahuan serta terobosan dalam rangka percepatan peningkatan kualitas pelayanan. Kementerian/Lembaga/ Daerah dihimbau mempercepat peningkatan kualitas pelayanan publik dengan membangun minimal satu inovasi setiap tahunnya, melalui kerjasama jaringan kerja pengembangan inovasi pelayanan publik dilakukan kompetisi dan pemberian penghargaan inovasi pelayanan publik.

Kerangka Berpikir: Berdasarkan latar belakang permasalahan sebagaimana telah diuraikan, maka disusun sebuah kerangka pikir model inovasi pelayanan adminduk yang menggambarkan bahwa permasalahan pelayanan adminduk, inovasi pelayanan yang ada saat ini, dan kebijakan pelayanan adminduk merupakan faktor-faltpr yang mempengaruhi kebutuhan akan inovasi pelayanan adminduk sehingga diperlukan persiapan model inovasi pelayanan adminduk yang dapat direplikasi.

Langkah strategis yang perlu dilakukan dalam upaya peningkatan kualitas pelayanan adminduk adalah penerapan model inovasi pelayanan adminduk terbaik yang dapat direplikasi. Penerapan model tersebut terdiri dari langkah-langkah yang berawal dari persiapan model inovasi pelayanan adminduk, ujicoba dan finalisasi penerapan model inovasi pelayanan adminduk kreasi baru (lihat gambar 2).

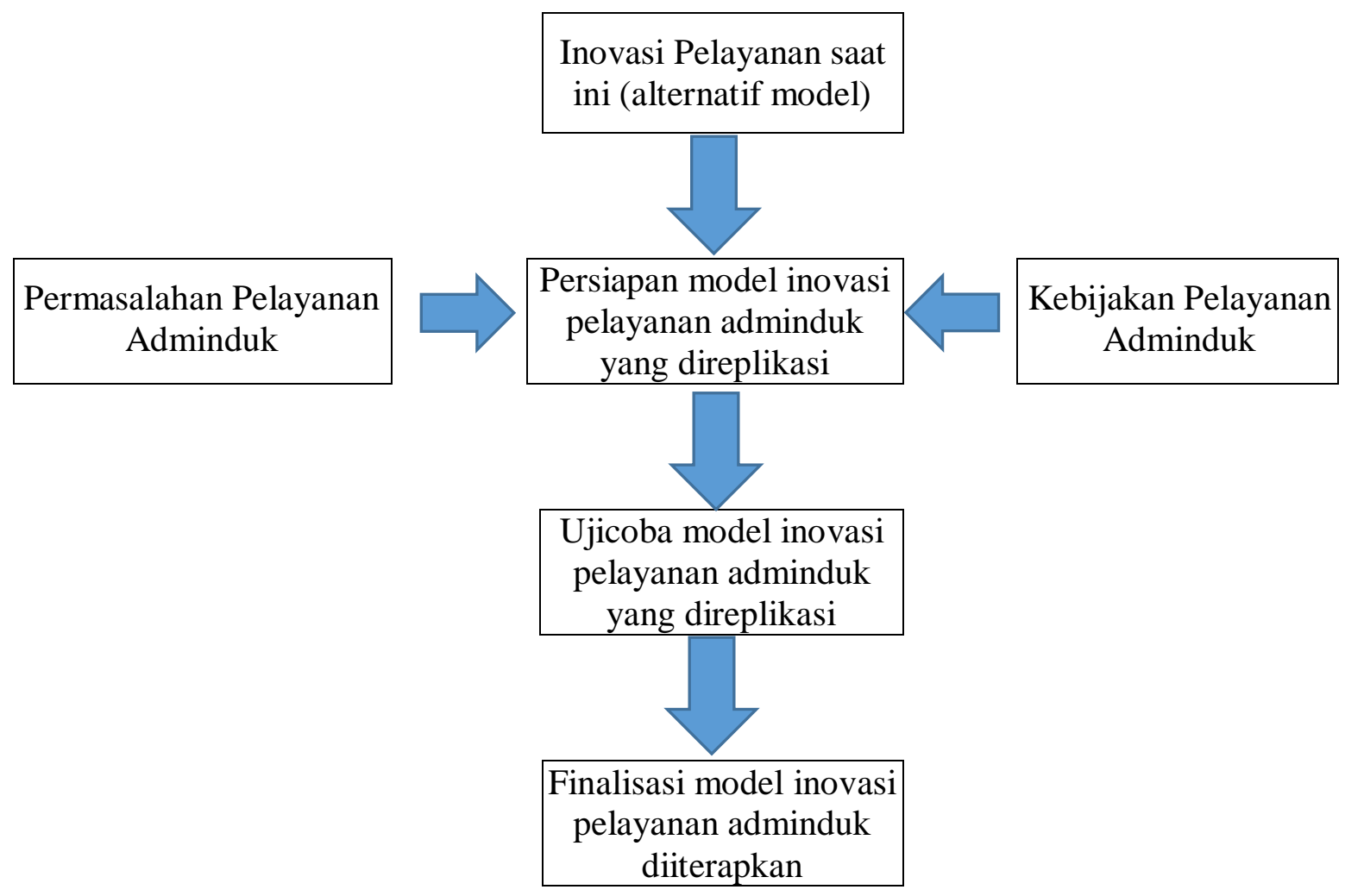

Gambar 2. Kerangka pikir model inovasi pelayanan adminduk (Sumber: Diolah dari berbagai sumber (Apeksi-Transformasi GIZ 2016; LAN 2017; Permendagri No.7/2019 dan PP No. 38/2017)). 
Kerangka pikir tersebut digunakan sebagai acuan dalam menjawab pertanyaan penelitian, sebagai berikut: (1) Apa model inovasi pelayanan adminduk terbaik yang dapat direplikasi?; dan (2) Bagaimana cara mereplikasi model inovasi pelayanan adminduk tersebut?

Hasil penelitian yang relevan: Dari penelusuran terhadap hasil penelitian yang relevan, dijumpai 5 (lima) karya ilmiah yang terkait dengan penelitian ini, sebagai berikut: (1) Pengembangan model inovasi delivery service akta kelahiran di kota Bandung, oleh Wulandari Rejeki dan Yunni Susanty, Jurnal Ilmu Administrasi STIA-LAN Bandung, 2017; (2) Inovasi Pelayanan Administrasi Kependudukan Secara Online di Kabupaten Pati, oleh Tania Soraya, Semarang, Fisip-Undip, 2019; (3) Inovasi Pelayanan melalui Aplikasi Dukcapil Dalam Genggaman oleh Dinas Dukcapil Kota Surakarta oleh Anisa Cahyaningrum \& Rino Ardhian Nugroho, Jurnal Ilmu Administrasi Publik, Medan, 2019; (4) Model Inovasi Pelayanan Kesehatan Melalui Program Gerakan Serentak Keluarga Siaga (Gertak Kasi): Studi Pada Puskesmas Bades Kecamatan Pasirian, Kab. Lumajang, oleh L.I. Mindarti, Jurnal Ilmu Administrasi, UPN Jatim, 2018; dan (5) Model Inovasi Pemerintah Daerah Bidang Pelayanan Perizinan dalam Mewujudkan Smart City (Studi Pendekatan Sistem Dinamik pada Pemerintah Kabupaten Sragen), oleh Rendra Eko Wismanu, Mohammad Nuh, Nurjati Widodo, Nana Abdul Aziz, Jurnal Ilmiah Administrasi, Universitas Brawijaya, 2019.

Studi tersebut berkaitan studi ini dalam fokus kajian model inovasi pelayanan. Diantara kelima studi tersebut, studi pertama, kedua, dan ketiga memiliki kesamaan fokus dengan studi ini, yaitu kesamaan fokusnya di bidang pelayanan adminduk secara umum. Adapun perbedaannya, yaitu: (1) Studi ini mengenai pelayanan adminduk di banyak lokus; sedangkan studi yang pertama tentang pelayanan akta kelahiran di kota Bandung yang dibatasi pada satu fokus dan lokus; (2) studi kedua dibatasi pada satu lokus; (3) studi ketiga dibatasi pada satu lokus pula; (4) studi yang keempat mengenai model inovasi pelayanan di bidang kesehatan; dan (5) studi yang kelima di bidang perizinan.

Jadi, meskipun ada persamaan fokus kajian model inovasi pelayanan namun berbeda bidangnya. Di samping itu, lokus studi ini lebih luas dari studi lainnya. Dengan demikian, studi model inovasi pelayanan adminduk ini merupakan studi yang baru dilakukan, dan diharapkan hasilnya dapat berguna untuk melengkapi studi sebelumnya.

\section{Metode Penelitian}

Penelitian dilakukan menggunakan metode studi pustaka dengan analisis dekriptif kualitatif. Penelitian ini mengumpulkan data sekunder. Data sekunder yang dikumpulkan bersumber dari peraturan perundang-undangan, kebijakan pemerintah, laporan/ hasil penelitian sebelumnya dengan memanfaatkan media tertulis, cetak dan elektronik termasuk website.

Teknik penentuan sampel dilakukan dengan teknik Accidental Sampling dengan mengambil sampel yang ditemukan secara kebetulan karena cocok digunakan untuk sumber data (Sugiyono 2009: 85). Sampel yang digunakan adalah instansi pemerintah yang mempunyai tugas di bidang pelayanan adminduk yang inovasinya mendapatkan penghargaan inovasi pelayanan publik top-99, dalam hal ini dibatasi 10 (sepuluh) instansi (kementerian/ lembaga/daerah).

Tahapan pengumpulan data sekunder dilakukan dengan mengumpulkan data dan informasi inovasi pelayanan adminduk sampel tersebut; dan mengolahnya dengan cara dikelompokan sesuai dengan focus penelitian, kemudian hasilnya disajikan ke dalam bentuk tabel. Selanjutnya, analisis data kualitatif digunakan untuk menjelaskan model inovasi pelayanan adminduk terbaik di Indonesia berdasarkan kecendurungan perolehan data, 
Wisber Wiryanto

selanjutnya dijelaskan cara mereplikasi model inovasi pelayanan adminduk tersebut. Penelitian ini dilakukan di Jakarta pada semester pertama tahun 2020.

\section{Hasil dan Pembahasan}

Hasil: Perolehan data berupa identifikasi nama instansi, inovasi dan jenis inovasi pelayanan adminduk (lihat tabel 1). Pertama, instansi yang disajikan sebanyak 10 (sepuluh), meliputi 1 (satu) instansi kementerian; 2 (dua) pemerintah provinsi; 3 (tiga) pemerintah kota; dan 4 (empat) pemerintah kabupaten. Sebagai sampel adalah instansi yang mempunyai kewenangan pelayanan adminduk. Kedua, inovasi yang disajikan merupakan inovasi pelayanan adminduk terbaik dengan penghargaan top-99. Ketiga, jenis yang disajikan berkaitan dengan inovasi pelayanan dalam upaya peningkatan kualitas pelayanan adminduk.

Data yang disajikan menunjukkan instansi yang bersangkutan (tabel 1, kolom 1) melakukan inovasi pelayanan adminduk terbaik dan diberikan penghargaan terbaik top-99 (diantaranya juga top-45 \& 40) pada kompetisi inovasi pelayanan publik dalam 3 (tiga) tahun terakhir 2018, 2019, 2020 (kolom 2), dan hasil indentifikasi inovasi berdasarkan jenisnya (kolom 3) meliputi terintegrasi, online-daring, dan jemput bola.

Tabel 1. Inovasi Pelayanan Adminduk Top 99 dan jenisnya tahun 2018, 2019 dan 2020

\begin{tabular}{|c|c|c|}
\hline Instansi & Inovasi & Jenis \\
\hline (1) & (2) & (3) \\
\hline \multirow[t]{3}{*}{$\begin{array}{l}\text { 1. Kementerian } \\
\text { Dalam Negeri }\end{array}$} & $\begin{array}{l}\text { I-Pop: Indonesia Population \& Civil Registration Map } \\
\text { (Peta Dukcapil Indonesia) }\end{array}$ & $\begin{array}{l}\text { Inovasi } \\
\text { terintegrasi }\end{array}$ \\
\hline & $\begin{array}{l}\text { Si Juwita (Pemanfaatan data kependudukan terintegrasi \& } \\
\text { online untuk mewujudkan Single identity Number), Ditjen } \\
\text { Dukcapil }\end{array}$ & $\begin{array}{l}\text { Inovasi } \\
\text { terintegrasi, online } \\
\text { daring }\end{array}$ \\
\hline & $\begin{array}{l}\text { Super tajam (Surat pernyataan tanggungjawab mutlak } \\
\text { sebagai solusi penerbitan akta kelahiran) Ditjen Dukcapil } \\
{[+ \text { Top 45] }}\end{array}$ & $\begin{array}{l}\text { Inovasi } \\
\text { terintegrasi }\end{array}$ \\
\hline $\begin{array}{l}\text { 2. Pemprov DKI } \\
\text { Jakarta }\end{array}$ & $\begin{array}{l}\text { Si mas gesit (Sistem adminduk berbasis informasi } \\
\text { elektronik) }\end{array}$ & Inovasi online \\
\hline $\begin{array}{l}\text { 3. Pemprov } \\
\text { Kalimantan Utara }\end{array}$ & $\begin{array}{l}\text { Si Pelandukilat (Sistem pelayanan adminduk di wilayah } \\
\text { Perbatasan dan Pedalaman) [+Top 45] }\end{array}$ & $\begin{array}{l}\text { Inovasi jemput } \\
\text { bola }\end{array}$ \\
\hline 4. Pemko Surakarta & Program KIA dan sistem relasi pencatatan kelahiran & \begin{tabular}{|l|l|}
$\begin{array}{l}\text { Inovasi } \\
\text { terintegrasi }\end{array}$ \\
\end{tabular} \\
\hline 5. Pemko Pasuruan & Peterpan (Pelayanan terpadu Hak Sipil Anak) & $\begin{array}{l}\text { Inovasi } \\
\text { terintegrasi }\end{array}$ \\
\hline 6. Pemko Surabaya & $\begin{array}{l}\text { Program } 6 \text { in } 1 \text { (pengurusan akta lahir, kematian, } \\
\text { perkawinan, perceraian, surat pindah datang/keluar } \\
\text { daring) [+Top 40] }\end{array}$ & $\begin{array}{l}\text { Inovasi } \\
\text { terintegrasi, online } \\
\text { daring }\end{array}$ \\
\hline 7. Pemkab Aceh Barat & $\begin{array}{l}\text { Aklamasi dansa (akta kelahiran/kematian terintegrasi dana } \\
\text { desa) }\end{array}$ & Inovasi terintegras \\
\hline $\begin{array}{l}\text { 8. Pemkab } \\
\text { Dharmasraya }\end{array}$ & $\begin{array}{l}\text { Sad to happy (Suku anak dalam terobos hutan demi } \\
\text { adminduk Dharmasraya) }\end{array}$ & $\begin{array}{l}\text { Inovasi } \\
\text { terintegrasi }\end{array}$ \\
\hline $\begin{array}{l}\text { 9. Pemkab } \\
\text { Banyuasin }\end{array}$ & $\begin{array}{l}\text { Jam kunci (Jemput bola rekam KTP-el langsung cetak } \\
\text { ditempat) }\end{array}$ & $\begin{array}{l}\text { Inovasi jemput } \\
\text { bola }\end{array}$ \\
\hline $\begin{array}{l}\text { 10. Pemkab Penukal } \\
\text { Abab Lematang Ili }\end{array}$ & $\begin{array}{l}\text { Sagarurung keli salai (Siaga urusan penting kependudukan } \\
\text { melalui aplikasi sampai selesai) }\end{array}$ & $\begin{array}{l}\text { Inovasi online- } \\
\text { daring }\end{array}$ \\
\hline
\end{tabular}

Sumber: Menpan.go.id (2018, 2019, 2020), data diolah. 
Hasil penelitian menunjukkan ada 12 (duabelas) inovasi pelayanan adminduk top-99 berdasarkan identifikasi jenisnya dari yang terbanyak hingga yang sedikit dilakukan, sebagai berikut: (1) inovasi layanan adminduk secara terintegrasi, merupakan yang terbanyak dilakukan; (2) inovasi layanan adminduk online-daring, merupakan yang cukup banyak dilakukan; dan (3) inovasi layanan adminduk jemput bola, merupakan yang sedikit dilakukan. Inovasi tersebut ada yang tunggal atau campuran dari jenis inovasi tersebut di atas. Kemendagri merupakan instansi yang terbanyak mendapat penghargaan inovasi pelayanan publik top-99.

Pembahasan: Berdasarkan hasil penelitian, ada 12 (duabelas) inovasi pelayanan adminduk top-9, sebagaimana disajikan (tabel 1). Beberapa diantaranya telah mendapatkan apresiasi dari pemangku kepentingan sebagai model inovasi pelayanan adminduk yang dapat direplikasi untuk meningkatkan kualitas pelayanan adminduk di Indonesia.

Contohnya, inovasi Super tajam (Surat pernyataan tanggungjawab mutlak sebagai solusi penerbitan akta kelahiran) merupakan inovasi pelayanan adminduk terbaik (top-99 \& 45, tahun 2019) yang dilakukan oleh instansi Kemendagri. Oleh karena itu, pemangku kepentingan Kemendagri berharap ke depan inovasi Supertajam tersebut dapat direplikasi untuk Supertajam perkawinan, perceraian kematian maupun untuk dokumen kependudukan yang lain (Menpan.go.id 2019).

Inovasi pelayanan adminduk top-99 lainnya yaitu yang telah mendapatkan penghargaan sebelum tahun 2018, juga masih dapat dijadikan sebagai model inovasi yang dapat direplikasi. Contoh, inovasi KIA (Kartu Insentif Anak) dari Pemko Surakarta (Top 33, 25, 99 tahun 2014, 2015, 2017); dan inovasi Kakeku Datang (Kartu keluargaku data ulang) dari Pemkab Gresik (Top 99 tahun 2016). Jika inovasi tersebut dapat diterapkan di daerah lain, akan membawa peningkatan pelayanan publik secara nasional (Kemenpanrb 2018).

Selain itu, ada inovasi pelayanan adminduk lainnya meskipun belum mendapatkan penghargaan top-99 tetapi mendapatkan apresiasi dari pemangku kepentingan, juga dapat dijadikan sebagai model inovasi pelayanan adminduk untuk direplikasi.

Contohnya, inovasi Chattbot Gisa (Gerakan Indonesia Sadar Adminduk) oleh Kemendagri. Dengan memanfaatkan inovasi tersebut, maka layanan dukcapil dapat terus berjalan, di tingkat nasional dan daerah, tanpa kontak langsung dengan menerapkan standar informasi. Masyarakat bisa bertanya layaknya percakapan dengan seorang petugas, mengenai prosedur pembuatan KTP dan KK, syarat pencatatan pernikahan, akta kelahiran, informasi biaya, secara cepat dan akurat. Dengan tersedianya informasi tersebut, masyarakat terhindar bolak-balik ke kantor layanan karena persyaratan yang tidak lengkap. Itulah bentuk perubahan pelayanan adminduk, mekanisme, sistem prosedur pelayanan yang manual menjadi online. Inovasi ini diharapkan bisa diduplikasi oleh Dinas Dukcapil seluruh Indonesia (Ombudsman.go.id 2020).

Akhirnya, bagaimana cara mereplikasi model inovasi pelayanan adminduk tersebut? Untuk menjawab pertanyaan, maka sejalan dengan konsep bahwa model dapat diartikulasikan dalam bentuk gambar, bagan, atau skema (LAN 2017); dengan memperhatikan tinjauan pustaka, kerangka berpikir, dan hasil penelitian, maka diusulkan sebuah replikasi model inovasi pelayanan adminduk (lihat gambar 3).

Model inovasi pelayanan adminduk dan replikasinya tersebut menjelaskan hubungan keterkaitan kebijakan upaya peningkatan kualitas pelayanan adminduk merupakan faktor pendorong dilakukannya inovasi dalam berbagai jenis; dan replikasi model inovasi pelayanan adminiduk, sebagai berikut: 
Pertama, upaya peningkatan kualitas pelayanan adminduk mendorong dilakukannya inovasi dalam berbagai jenis: (1) inovasi layanan terintegrasi; (2) inovasi layanan jemput bola; (3) inovasi jadwal/waktu pelayanan; (4) inovasi layanan dukcapil go digital; (5) inovasi anjugan dukcapil mandiri; dan (6) inovasi layanan adminduk secara daring (online) termasuk sebuah layanan yang dioptimalkan selama pandemic Covid-19 dengan menerapkan protokol kesehatan. Jenis inovasi tersebut merupakan representasi dari inovasi yang dilakukan (lihat tabel kolom 2, dan deskripsi hasil penelitian) oleh instansi pemerintah yang menyelenggarakan fungsi pelayanan adminduk. Dalam hal ini, instansi Ditjen Dukcapil Kemendagri, Dinas Dukcapil Provinsi/ Kabupaten/Kota (lihat tabel 1, kolom 1).

Kedua, replikasi model inovasi pelayanan adminduk. Proses replikasi model inovasi terdiri dari: (1) kegiatan memilih dan menetapkan inovasi untuk dijadikan sebagai sebuah model yang akan diterapkan atau dicontoh. Pemilihan/penetapan model inovasi tersebut dilakukan dengan memperhatikan jenis inovasi (bila perlu diketahui tipologinya). Hal ini dilakukan untuk memastikan adanya kesesuaian model inovasi tersebut dengan kebutuhan instansi yang bersangkutan; sehingga memudahkan replikasi model inovasi tersebut. (2) Persiapan penerapan model inovasi. Hal yang dipersiapkan adalah menentukan cara mereplikasi model inovasi yang ditawarkan melalui adopsi, adaptasi atau modifikasi.

\section{Upaya peningkatan kualitas pelayanan adminduk menurut jenis inovasi:}
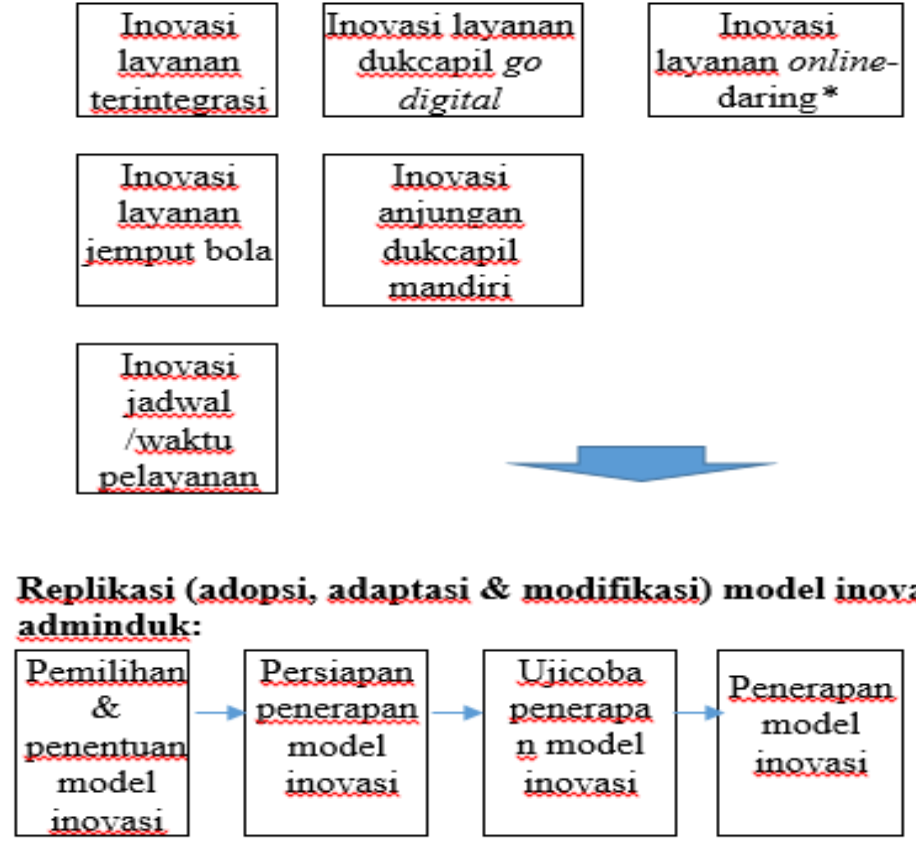

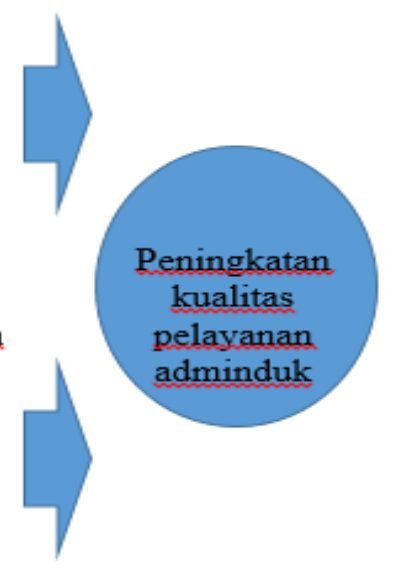

Gambar 3. Model inovasi pelayanan adminduk dan replikasinya. (Sumber: Dolah dari berbagai sumber (LAN 2017; Menpan.go.id 2018, 2019, 2020; Permendagri No.7/2019; dan PP No. 38/2017)).

Keterangan: *) Termasuk inovasi layanan online-daring selama pandemi Covid-19 dengan penerapan protokol kesehatan. 
Apabila memilih adopsi maka inovasi tersebut dapat langsung diterapkan penggunaannya. Contohnya, inovasi pelayanan anjungan dukcapil mandiri (inovasi oleh Kemendagri) apabila dijadikan sebagai sebuah inovasi yang akan dicontoh, maka model tersebut dapat langsung diterapkan oleh instansi dinas dukcapil yang bersangkutan, karena perangkat ADM tersebut sudah disediakan oleh Kemendagri.

Tidak semua inovasi bisa diadopsi langsung, melainkan perlu dilakukan dengan cara adaptasi atau modifikasi. Contohnya, inovasi kakeku datang (Kartu keluargaku data ulang oleh dinas dukcapil Pemkab Gresik, merupakan sebuah inovasi pelayanan publik top-99 tahun 2016) apabila dijadikan sebagai sebuah inovasi yang akan dicontoh, maka model tersebut perlu diujicoba penerapannya, agar sesuai dengan kondisi lingkungan setempat atau ada bagian dari model inovasi tersebut yang perlu disesuaikan dengan kebutuhan di tempat penerapannya, baru kemudian dilakukan implementasi model inovasi replikasi tersebut.

Model tersebut bisa digunakan sebagai sebuah instrumen dalam kerjasama antar daerah untuk mereplikasi inovasi daerah lainnya. Contohnya, instansi dukcapil pemkab Halmahera tertarik mencontoh inovasi dukcapil pemko Bengkulu (Klikwarta.com 2020). Maka bisa menggunakan model inovasi pelayanan adminduk dan replikasinya tersebut.

Dengan demikian, model inovasi pelayanan adminduk dan replikasinya tersebut menggambarkan adanya hubungan keterkaitan antara upaya peningkatan kualitas pelayanan adminduk yang mendorong berbagai jenis inovasi; dan replikasi model inovasi pelayanan adminduk yang bertujuan untuk meningkatkan kualitas pelayanan adminduk.

\section{Kesimpulan}

1. Ada 12 (duabelas) inovasi pelayanan adminduk terbaik top-99 tahun 2018, 20N 19 dan 2020 yang dapat direplikasi, nama inovasi dan asal instansi, sebagai berikut: (1) I-Pop: Indonesia Population \& Civil Registration Map oleh Ditjen Dukcapil Kemendagri; (2) Si Juwita oleh Ditjen Dukcapil Kemendagri; (3) Super tajam oleh Ditjen Dukcapil Kemendagri; (4) Si mas gesit oleh Pemprov DKI Jakarta; (5) Si Pelandukilat oleh Pemprov Kalimantan Utara; (6) Program KIA dan sistem relasi pencatatan kelahiran oleh Pemko Surakatra; (7) Peterpan oleh Pemko Pasuruan; (8) Program 6 in 1 oleh Pemko Surabaya; (9) Aklamasi dansa oleh Pemkab Aceh Barat; (10) Sad to happy oleh Pemkab Dharmasraya; (11) Jam kunci oleh Pemkab Banyuasin; dan (12) Sagarurung keli salai oleh Pemkab Penukal Abab Lematang Ilir.

2. Replikasi model inovasi pelayanan adminduk yang terbaik dilakukan berdasarkan: (1) adanya kebijakan upaya peningkatan kualitas pelayanan adminduk yang mendorong munculnya jenis inovasi: (a) inovasi terintegrasi, (b) inovasi jemput bola, (c) inovasi jadwal/ waktu pelayanan, (d) inovasi layanan dukcapil go digital, (e) inovasi anjungan dukcapil mandiri, dan (f) inovasi online-daring termasuk inovasi layanan selama pandemi Covid-19 dengan penerapan protokol kesehatan; dan (2) adanya kebutuhan replikasi inovasi pelayanan adminduk terbaik untuk peningkatan kualitas pelayanan adminduk, dengan cara adopsi, adaptasi, dan modifikasi; melalui langkah-langkah replikasi, sebagai berikut: (a) pemilihan dan penentuan model inovasi; (b) persiapan penerapan model inovasi; (c) ujicoba penerapan model inovasi; dan (d) penerapan model inovasi yang direplikasi. 
INOBIS: Jurnal Inovasi Bisnis dan Manajemen Indonesia Vol.03, No.01, Bulan Desember 2019

Wisber Wiryanto

\section{Saran}

1. Instansi pelayanan adminduk perlu mereplikasi model inovasi terbaik dalam upaya peningkatan kualitas pelayanan adminduk di Indonesia, menggunakan model inovasi pelayanan adminduk dan replikasinya yang telah disusun.

2. Mengingat keterbatasan penelitian ini hanya menggunakan metode penelitian kepustakaan, diharapkan peneliti lainnya dapat melakukan penelitian baru antara lain dengan cara menggunakan metode penelitian yang berbeda untuk memperluas penelitian ini.

\section{Daftar Pustaka}

Apeksi-Transformasi (GIZ). 2016. Delapan Langkah Transfer Inovasi Pelayanan Publik.

Cahyaningrum, A, dan Nugroho, R.A. 2019. Inovasi Pelayanan melalui Aplikasi Dukcapil Dalam Genggaman oleh Dinas Dukcapil Kota Surakarta. Jurnal Ilmu Administrasi Publik: 103-115.

Departemen Pendidikan dan Kebudayaan. 2008. Kamus Besar Bahasa Indonesia, PT Gramedia Pustaka Utama.

Kementerian Pendayagunaan Aparatur Negara dan Reformasi Birokrasi. 2018. Diakses dari https://www.menpan.go.id/site/berita-terkini/mencari-model-inovasi-layanandukcapil-yang-dapat-direplikasi, tanggal 10 Juni 2020.

Klikwarta.com. 2020. Diakses dari https://www.klikwarta.com/dukcapil-halmahera-selatantertarik-copy-inovasi-dukcapil-kota-bengkulu, tanggal 20 Juli 2020.

Lembaga Administrasi Negara. 2017. Pedoman Replikasi Inovasi, Jakarta: 16-18.

Menpan.go.id. 2018. Diakses dari https://www.menpan.go.id/site/berita-terkini/kementerianpanrb-tetapkan-top-40-inovasi-pelayanan-publik-2018, tanggal 15 Juni 2020.

Menpan.go.id. 2018. Diakses dari https://www.menpan.go.id/site/download/file/5713pengumuman-tentang-top-99-inovasi-pelayanan-publik-tahun-2018, tanggal 30 Juni 2020.

Menpan.go.id. 2019. Diakses dari https://www.menpan.go.id/site/berita-terkini/kementerianpanrb-tetapkan-top-45-inovasi, tanggal 15 Juni 2020.

Menpan.go.id. 2019. Diakses dari https://www.menpan.go.id/site/publikasi/unduhdokumen/surat/file/6045-daftar-top-99-sinovik-tahun-2019, tanggal 15 Mei 2020.

Menpan.go.id. 2020. Diakses dari https://www.menpan.go.id/site/publikasi/unduhdokumen/surat/file/6260-pengumuman-tentang-top-99-inovasi-pelayanan-publiktahun-2020, tanggal 10 Juli 2020.

Mindarti, L.I. 2018. Model Inovasi Pelayanan Kesehatan Melalui Program Gerakan Serentak Keluarga Siaga (Gertak Kasi): Studi Pada Puskesmas Bades Kecamatan Pasirian, Kab. Lumajang. Jurnal Ilmu Administrasi. UPN Jawa Timur: 103-111.

Rejeki, P.W. dan Susanty, Y. 2017. Pengembangan model inovasi delivery service akta kelahiran di kota Bandung, Jurnal Ilmu Administrasi. STIA-LAN Bandung: 139-151.

Soraya, T. 2019. Inovasi Pelayanan Administrasi Kependudukan Secara Online di Kabupaten Pati, FISIP Universitas Diponegoro: 1-10.

Sugiyono. 2009. Metode Penelitian Kuantitatif, Kualitatif dan R\&D. Penerbit Alfabeta.

Surat Kementerian Dalam Negeri No. 443.1/2978/Dukcapil per 16 Maret 2020 (yang telah diperpanjang masa berlakunya hingga pandemi Covid-19 berakhir).

Tempo. 2020. Diakses dari https://koran.tempo.co/read/internasional/454713/kematianglobal-akibat-covid-19-tembus-setengah-juta-jiwa, tanggal 10 Juli 2020. 
INOBIS: Jurnal Inovasi Bisnis dan Manajemen Indonesia

Vol.03, No.01, Bulan Desember 2019

Wisber Wiryanto

Utomo, T.W.W. 2014. Diakses dari https://www.slideshare.net/triwidodowutamo/inovasipelayanan-publik-prospek-kebutuhan-inovasi-pelayanan-lan, tanggal, 8 Juli 2020.

Utomo, T.W.W. 2017. Inovasi Harga Mati: Sebuah Pengantar Inovasi Administrasi Negara. PT RajaGrafindo Persada.

Wismanu, R.E. et.al. 2019. Model Inovasi Pemerintah Daerah Bidang Pelayanan Perizinan dalam Mewujudkan Smart City (Studi Pendekatan Sistem Dinamik pada Pemerintah Kabupaten Sragen). Jurnal Ilmiah Administrasi Publik. Universitas Brawijaya Malang: 369-376. 